\title{
А. Ф. РЕБРОВ - ОСНОВОПОЛОЖНИК ОТЕЧЕСТВЕННОГО ШЕЛКОВОДСТВА НА СЕВЕРНОМ КАВКАЗЕ В ПЕРВОЙ ПОЛОВИНЕ ХІХ ВЕКА
}

В данной статье автор обращается к проблеме развития отечественного шелководства на Северном Кавказе в первой половине XIX века. Использование комплекса опубликованных источников и архивных документов позволило выявить основные этапы становления и развития шелководства в рассматриваемый период. При изучении темы автором использовались фонды Государственного архива Ставропольского края, статьи из дореволюционных газет и журналов, и впервые в контексте данного вопроса был рассмотрен нарратив французского путешественника Ксавье Оммер де Гелль, переведенный автором

Важную роль в развитии шелководства занимает деятельность А. Ф. Реброва, который одним из первых приступил к развитию и распространению отечественного шелководства на Северном Кавказе. А. Ф. Ребров использовал научные методы. Так, путем экспериментирования и отбора, им были выведены новые породы тутового шелкопряда и тутовых деревьев, таких как Alba morus, созданы благоприятные температурные условия и усовершенствована технология выкормки червей тутового шелкопряда.

А. Ф. Ребров был заинтересован в развитии шелководства не только на территории Северного Кавказа, но и в соседних губерниях. В связи с этим, в его имении
Владимировке была открыта школа по изучению шелководческого дела для крестьянских детей и всех желающих на бесплатной основе. Были открыты школы по изучению шелководства и в Ставрополе, Кизляре, Кисловодске, Москве, Санкт-Петербурге. Безвозмездная раздача саженцев тутовых деревьев и грены шелкопряда, все это способствовало развитию отечественного гренопроизводства и распространению шелководческой отрасли в России.

Успешное развитие шелководства подтверждалось качественным шелком, производимым в имении А. Ф. Реброва, который по своей белизне конкурировал с французскими, итальянскими и китайскими шелками. Обладая энциклопедичностью знаний, успехами в хозяйстве, А. Ф. Ребров был назначен почетным директором первой сельскохозяйственной выставки в городе Ставрополе и личным экскурсоводом императора Николая І. При посещении имения Владимировки государственными деятелями, предпринимателями и иностранцами, сельскохозяйственная деятельность помещика Реброва была удостоена высоких оценок и отзывов.

Ключевые слова: А. Ф. Ребров, шелководство на Северном Кавказе, гренопроизводство, имение Владимировка, хозяйственное освоение Кавказа, историческая биографика.

\section{A. F. REBROV - THE FOUNDER OF NATIONAL SERICULTURE IN THE NORTH CAUCASUS IN THE FIRST HALF OF THE NINETEENTH CENTURY}

The author studies the development of domestic sericulture in the North Caucasus in the first half of the XIX century. The use of a set of published sources and archival documents allowed to identify the main stages of formation and development of sericulture in the period under consideration. In studying this problem, the author used the funds of the state archive of the Stavropol territory, articles from pre-revolutionary newspapers and magazines, and for the first time in the context of the issue the narrative of the French traveler Xavier Ommer de Gell, that was translated by the author

An important role in the development of sericulture played the activity of A. F. Rebrov, who was one of the first to begin the development and the spread of domestic sericulture in the North Caucasus. A. F. Rebrov used scientific methods. By means of experimentation and selection new breeds of silkworm and mulberry trees, such as Alba morus were bred, favorable temperature conditions were specified and improved technology of feeding silkworms was created.

A. F. Rebrov was interested in the development of sericulture not only in the North Caucasus, but also in the neigh- boring provinces. In this regard, in his estate Vladimirovka a free of charge school for the study of sericulture for peasant children and all comers was opened. The schools for the study of sericulture were opened in Stavropol, Kizlyar, Kislovodsk, Moscow and St. Petersburg. Gratuitous distribution of mulberry trees and silkworm seedlings contributed to the development of domestic green production and the spread of the silk industry in Russia.

The successful development of sericulture was confirmed by high-quality silk produced in the estate of A. F. Rebrov, which in its whiteness competed with French, Italian and Chinese silks. Having encyclopedic knowledge, success in the economy, A. F. Rebrov was appointed honorary Director of the first agricultural exhibition in the city of Stavropol and personal guide of the Emperor Nicholas I. Having visited the estate of Vladimirovka, statesmen, entrepreneurs and foreigners appreciated the agricultural activities of the landowner Rebrov.

Key words: A. Rebrov, sericulture in the North Caucasus, silkworm production, Vladimirovka estate, economic development of the Caucasus, historical biography. 
Тема развития шелководства на Северном Кавказе в первой половине XIX века является актуальной. Например, об востребованности проблемы свидетельствуют защита кандидатской диссертации в 2011 году Алимирзаевым Н. Я. В первой главе данной диссертации в одном из параграфов «А. Ф. Ребров - один из основателей русского шелководства», показаны лишь некоторые аспекты развития шелководства А. Ф. Ребровым на Северном Кавказе [1]. Поэтому целесллбразно дальнейшее обращение к биографии А. Ф. Реброва и его вкладу в хозяйственное освоение Северного Кавказа. Контекстно к теме обращаются такие историки как Клычников Ю. Ю., Богословский В. В., Лейнвебер Е. Ф., Фадеев А. В. $[3 ; 27 ; 32]$. С 2011 года проводятся традиционные Ребровские музейно-краеведческие чтения в историко-краеведческом музее «Крепость» города Кисловодска и Ребровские районные музейные чтения в Левокумском историко-краеведческом музее им. В. Р. Ясинова. Соответственно, интерес к личности А. Ф. Реброва наблюдается как на научном, так и на культурном уровне. Через особенности биографии и историю трудовой деятельности данного исторического фигуранта есть возможность с новых сторон посмотреть и на историю отрасли шелководства в России, а также на социально-экономическую историю Северного Кавказа.

Целью статьи является изучение фрормы и методов хозяйственной деятельности А. Ф. Реброва, которые, несмотря на жесткие условия крепостнической системы и климатические особенности зоны полупустыни Ногайской степи, способствовали достижению высоких результатов в развитии шелководства в имении Владимировке. Впервые в изучении деятельности А. Ф. Реброва используется нарратив иностранца, а именно французского путешественника Ксавье Оммер де Гелля.

Прохождение «Великого шелкового пути» через территорию Северного Кавказа сыграло большую роль в его экономическом развитии, а также в распространении технологий изготовления шелка среди местного населения [12, с. 119]. В начале XVIII века правительство Российской империи предприняло попытки, направленные на развитие отечественного шелководства на юге страны. Петр | считал необходимым приобщить к занятию шелководством предпринимателей, купцов и других частных лиц. Поэтому одним из первых, кому были предоставлены земля и право на выращивание и эксплуатацию шелковичных насаждений в городе Кизляре, стал армянский купец Сафар Васильев [27, с. 2]. В 1718 году на левом берегу Терека возникло имение Шелкозаводское, которым управлял С. Васильев. В связи с этим вблизи имения был построен завод по переработке шелка-сырца, на котором работали кизлярские казаки, армяне и грузины. С деятельностью армянских купцов связано начало продвижения шелководства в центральные районы Северного Кавказа [8, л. 14], [12, с. 119].

В 1799 году были изданы первые правила по ведению шелководства на территории Крыма,
Кавказа, Астрахани и других губерний, которые должны были стимулировать развитие шелководства, а также сделать его незаменимой частью сельскохозяйственной деятельности крестьян. $[23$, с. 130]. С учреждением на Кавказе в 1800 г инспекции по шелководству, целью ставился дальнейший подъем шелководства с базой в Кизляре. Инспекцию возглавляли такие видные деятели как М. Биберштей ${ }^{1}$, Х. Х. Стевен, Вишняков и другие. М. Биберштейн положил начало развитию шелководства в Грузии, но, несмотря на свою должность инспектора шелководства в Южной России, как настоящий ботаник, он все-таки больше внимания уделял изучению флоры и фрауны. По этой причине шелководство на Северном Кавказе развивалось крайне медленно. [12, с.120]

С назначением в 1816 году на должность главноуправляющего в Астраханской, Кавказской губерниях и в Грузии генерал-лейтенанта А. П. Ермолова, на Северном Кавказе наступает новый этап экономического развития. А. П. Ермолов с большим вниманием относился к подбору кадров для управления Кавказом. Именно кадровая политика стала отправной точкой знакомства А. П. Ермолова и А. Ф. Реброва, который стал его незаменимым помощником. Для этого он обладал всеми необходимыми профессиональными и личными качествами. А. Ф. Ребров с детства приучался отцом Федором к труду, самостоятельности и ответственности. С юности он наблюдал за отцом, который был приглашен в имение помещиков Хастатовых. Ф. А. Ребров успешно проводил свои опыты в сельском хозяйстве и при этом добивался превосходных результатов, например, им была выведена высокоустойчивая к засухе пшеница. Под его руководством в имени были заложены виноградники и получены новые сорта винограда, а немного позже был построен спиртокурительный завод. Отцовские начинания и опыты, проведенные для развития сельского хозяйства, нашли свое отражение в судьбе А. Ф. Реброва [16, с. 101-102].

С 1816 года А. П. Ермолов уделял большое внимание развитию виноградарства и шелководства в Грузии. Рассмотрев ситуацию, связанную с развитием шелководства на Кавказе и деятельностью инспекции, А. П. Ермолов, как покровитель кавказских шелководов, остался недоволен $[4$, л. 14]. В 1817 году он предложил А. Ф. Реброву заняться развитием шелководства на территории Северного Кавказа. В своем имении Владимировка, которое было получено как приданное за женою (еще в 1804 году), А. Ф. Ребров заложил основы для последующего развития отрасли в регионе. К концу 1817 года ему удалось получить около 25 грамм грены и размотать из коконов около 1 кг шелка-сырца $[12$, с. 121].

Поскольку в России своего гренопроизводства не существовало, то А. Ф. Реброву приходилось выписывать грену² из Китая, Италии, Франции,

${ }^{1}$ В Германии известен под именем Фридриха Августа Маршала фон Биберштейна, в России - Федор Кондратьевич Биберштейн. Ученый-ботаник, путешественник.

2 Яйца тутового шелкопряда 
стран Аравийского полуострова [3, с. 122]. В связи с этим до 1826 года шелк, производимый в имении А. Ф. Реброва, практически не отличался от кизлярского (местного) шелка. Используя же лучшие методы отбора, качественного ухода и кормления, А. Ф. Ребров добился того, что коконы по величине, форме и цвету стали практически тождественными китайским $[12$, с. 121$]$.

А. Ф. Ребров тщательно изучал мировой опыт шелководства, следил за появлением книжных новинок и научных статьей в области развития шелководства. Для проведения научных наблюдений за выкормкой червей шелкопряда, А. Ф. Ребров расположил одну из 7 шелководень рядом со своим кабинетом. В своем имении Владимировка А. Ф. Ребров фрактически создал научную лабораторию. У него имелось несколько тутовых садов, в которых насчитывалось до 16 тысяч разных пород деревьев [28, с. 223]

В итоге А. Ф. Ребровым была разработана усовершенствованная система технологии производства шелка. После выводки коконы сортировались, затем поступали в размотку, которая осуществлялась в отдельном каменном строении. Там находились шелкомотальные снаряды, полученные в разное время из Франции и усовершенствованные местными умельцами под руководством А. Ф. Реброва [28, с. 223]. В 1829 году А. Ф. Ребров в письме к министру внутренних дел писал о первом шелкомотальном снаряде: «Образцы шелка, выделываемого и вымотанного в нынешнем 1829 г. в количестве до 2 с половиной пуд: из них № 1 в 3 кокона или нити на колесо обыкновенным образом; два других мотка ссученных. № 2 для основы и № 3 для утока, на вновь устроенной с ранних, коего шелк прямо с коконов из тазу прядется и навивается на катушки и вместе тростится» [7, л. 1]. А. Ф. Ребров пояснял, что данный снаряд уступает по технологии фабричным машинам, усовершенствованным в России. Это простое изобретение стало первым опытом производства в Кавказской области и в дальнейшем могло бы способствовать появлению мануфрактурного производства [7, л. 1об.], [11, с. 363] Позже, А. Ф. Ребровым была создана тростильная машина, на которую уже можно было насаживать 120 катушек и при работе только двух размотчиц изготавливать основу [28, с. 223].

В 1832 году А. Ф. Ребровым была продемонстрирована размотка коконов Московскому обществу сельского хозяйства. Позже министерством внутренних дел было сообщено помещику об итогах просмотра и испытании в действии изобретенной им машины для размотки конов:

«1. Машина была подвергнута испытанию в присутствии членов Общества Сельского Хозяйства и известнейших в Москве фабрикантов шелковых изделий, а равно в Московском Отделении Мануфактурного Совета; и признана могущею доставить большие выгоды для нашего шелководства.

2. Обществу известно, что помощью сего снаряда, и искусства обрабатывать шелк, вы довели оный до такого совершенства, что в Париже и Лионе шелка Ваши признаны одними из превосходнейших в Европе.

3. Что в прошедшем году представив отчет Обществу о своем шелководстве за 1833 год, вы изъявили готовность каждому показать способ производить превосходный белый шелк, подобный китайскому сина, если присланы к Вам будут люди, для обучения шелководству, не требуя за то никакой платы, даже принимая и содержание учеников на свой счет, и что повторение сего вызова, Вы сделали в отчете за 1834 г

4.Что Общество Сельского Хозяйства, уважив столь благонамеренный вызов, послало уже к Вам одного из участников Земледельческой школы» $[9$, л. 2].

Производство в имении А. Ф. Реброва качественного шелка свидетельствовало и о его спросе. Несмотря на расстояние и высокую цену предприниматели приезжали к помещику Реброву и покупали шелк и коконы. Еще в 1829 году крупным российским фобрикантом И. М. Кондрашевым во Владимировке был куплен шелк по цене 850 рублей ассигнациями за пуд. Этот шелк оказался пригодным для изготовления самых тонких и изящных тканей, обычно привозимых из-за границы. Позже, промышленники за пуд ребровского шелка платили 1400-1800 рублей, а другие же шелка продавались по цене 400-500 рублей за пуд. Что касалось качества и белизны шелка, то шелк А. Ф. Реброва конкурировал с шелками Европы и Востока. В 1837 году в «Земледельческом журнале» А. Ф. Ребров писал: «Шелк мой признан и во Франции лучшим из всех европейских шелков и получил всеобщую известность. Это подтверждается требованием на него и ныне из Лиона коммерческим домом Дюфур д' Арль» [20, c. 103].

Благоприятный климат, правильно выбранный режим кормления и развития шелкопряда, совершенствование процессов размотки коконов в тонкий шелк-сырец, изучение опытов работы европейских и китайских шелководов, все это способствовало значительному улучшению качества шелка в заведении А. Ф. Реброва [12, с. 122].

Опытным путем А. Ф. Ребров выявил влияние качества корма - листьев шелковицы - на скорость развития гусениц и шелконосность коконов. Он первым ввел в практику способ выкормки гусениц на «камышовых плетнях» в 4 яруса в специальных помещениях - червоводнях. До этого обычный способ выкормки червей был на земле [3, с. 122], [11, с. 362-363].

Развитию шелководства способствовало экспериментирование, которое неоднократно проводил А. Ф. Ребров. Например, в 1836 году, при снижении утренней температуры с 22,5 до 7,5 градусов по Цельсию, была замечена высокая смертность гусениц в период завивки коконов. При опыте 10 гусениц были помещены в подвал с температурой 12,5 градусов по Цельсию и из них только 4 завили коконы. Данным опытом было подтверждено значение температуры, необходи- 
мой для нормальной выкормки гусениц и завивки ими коконов $[12$, с. 122$]$

Единственным путем развития шелководства и шелкомотания А. Ф. Ребров видел в широком привлечении к этому делу крестьян. Поэтому им не только в имении Владимировке, но и на Российском уровне, были созданы школы шелководов в Ставрополе, Кизляре, Кисловодске, Москве и Санкт-Петербурге, в которых все желающие могли обучиться основам выращивания гусениц и переработки коконов [11, с. 363].

Первой была организована бесплатная школа шелководов во Владимировке, в которой зимой ребят учили не только грамоте, арифметике и Закону Божьему, но и шелководческому делу, а летом обучали приемам выкормки гусениц тутового шелкопряда и размотки коконов. Для сохранения и передачи из поколения в поколение навыков и опыта ведения шелководства в имении Владимировке крестьянских детей с детства приучали к занятию шелководческим делом. А. Ф. Ребров стремился к тому, чтобы шелководство, наряду с земледелием, скотоводством и ремеслом, также стало неотъемлемой частью крестьянских занятий $[21$, с. 50$]$.

Дпя успешного осуществления опытов в своем хозяйстве, А. Ф. Ребров систематически подготавливал из учеников высококвалифицированных мастеров шелководства и кокономотания. Лучшие мастера А. Ф. Реброва получали поощрения за успехи в шелкомотании и уходе за шелкопрядом. Так, Московским обществом сельского хозяйства были отмечены крестьяне имения Владимировки: управляющий заведением А. Ф. Реброва Ермакевич, был награжден серебряной медалью, а смотритель за шелководством М. Устинов подарком. В 1857 году Обществом было отмечено 25 лет успешной работы мастерицы А. Андреевой $[12$, с. 127].

В связи с тем, что большинство крестьян были неграмотные, А. Ф. Ребровым было предложено Комитету шелководства предоставить изображения шелкового червя во всех его периодических возрастах и видоизменениях до будущего оживления из яичка. Также к каждой такой картинке необходимо было присовокупить таблицу с указанием температуры оживления, содержания, количества корма и размещения по возрастам. А. Ф. Ребров в газете «Кавказ» писал: «...такое изображение в картинке и цифрры были бы понятнее книг и писаний, коих не всякий может удержать в памяти, особенно из простолюдинов» $[18$, c. 86].

В земледельческую школу А. Ф. Реброва на период обучения шелководству с 1834 по 1837 год Московским обществом сельского хозяйства был послан воспитанник детского приюта А. Авксентьев. Под руководством А. Ф. Реброва им были проведены опыты по сравниванию коконов шелкопряда разных пород. А. Авксентьев отбирал лучшие по плотности и большие по величине коконы шелкопряда разных пород и определял их производственную и экономическую ценность.
В выводах он подчеркивал необходимость разведения шелкопряда ценных пород, так как это способствовало бы экономической заинтересованности населения к занятию шелководством. За свое трудолюбие в земледельческой школе А. Ф. Реброва ученик Авксентьев был награжден похвальным листом [12, с. 122-123]. Позже им были присланы помещику Реброву несколько статей о шелководстве, которые были напечатаны в «Земледельческом журнале» $[13$, с. 251].

В развитии и распространении шелководства на Северном Кавказе было заинтересовано и государство. А. Ф. Ребров нашел покровительство в лицах министра фринансов А. К. Мейендорфра и генерал-губернатора А. А. Вельяминова, при содействии которых была получена из Китая хорошая порода червей $[5, \pi .2]$. Дело в том, что А. К. Мейендорф в 1829 году поступил на службу в Министерство ффинансов России. В этом же году он был определен агентом Министерства финансов во Франции по части мануфактурной промышленности и торговли. А. К. Мейендорф был заинтересован не только в развитии и распространении шелководства по всей России, но и в отечественном производстве шелка и его конкурентоспособности. В свою очередь, назначенный с 1831 по 1838 годы командующим войсками Кавказской линии и Черномории, начальником Кавказской области А. А. Вельяминов стремился всячески поддерживать развитие сельскохозяйственных отраслей на Северном Кавказе [2, с. 76]

В 1836 году, при содействии А. К. Мейендорфа, А. Ф. Реброву от управляющего Королевским садом К. Бове из Франции было отправлено небольшое количество грены. Об успехах разведения французской породы в имении Владимировке А. Ф. Ребров писал: «Она у меня размножена в Заведении и от нея заимствовалось уже за Кавказское общество шелководства, где должна скоро расшириться, судя по отзыву, полученному мною от управляющего там сею частью, Надворного Советника Орлавского, что со введением ея за Кавказом, само собою улучшится воспитание червей и самая размотка с них шелку в виде более правильном и преимущественном того, какой есть теперь» [5, л. 2.об. - 3]. Барон Мейендорф продолжал поставлять через министерство финансов помещику новые породы червей из Франции и с Тибета, так как А.Ф. Ребров стремился «.. сделать известными ... все породы червей шелковых» не только на Кавказе, но и в России [5, л. З.об.].

Министром финансов А. К. Мейендорфом, получившим во Франции образцы шелка, посланные А. Ф. Ребровым для определения их качества, был написан положительный отзыв: «Посланный мне Вами шелк в образцах возбудил всеобщее удивление всех больших знатоков в Париже. Никогда они не хотели верить, что сей шелк, выделан в России; сей шелк один из прекраснейших и лучше выделанных в свете и особенно употребляем для белого газа и не имеет ни малейшего недостатка, разве только недовольно 
плотный» [3, с. 123]. Полученный высокого качества шелк из французской породы был удостоен высокого отзыва от управляющего Королевским садом К. Бове. В самой же Франции признали превосходство кавказского шелка по отличительной белизне и через департамент мануфактур просили у помещика Реброва прислать воду с реки Кумы, в которой разматывались шелковые коконы [5, л. 3 - 3 об.].

За все время существования и развития шелководства в имении помещика Реброва было выведено 9 пород червей, которые отличались коротким или продолжительным периодом свивания коконов и белизной. Первая порода, которую выделял А. Ф. Ребров, была французская порода сина. Она отличалась умеренным поеданием шелковицы (Alba morus или Шатуть) и через 24 дня начинала свивать коконы, из которых получался сребровидный шелк. Затем А. Ф. Ребров выделял арабскую породу, черви которой по окраске были «темнодикаго» цвета, через 27 дней вили коконы, но по белизне шелка незначительно уступали французской породе. Далее А. Ф. Ребров выделял китайскую, тибетскую, австральскую, итальянскую, гиланскую, левантскую и соединенную породы $[17$, с. 160].

Будучи активным пропагандистом шелководства и расширения ареала его распространения в России, А. Ф. Ребров бесплатно раздавал крестьянам, заинтересовавшимся лицам семена шелковицы и грену тутового шелкопряда [3, с. 123]. Еще в 1832 году приехав в Москву, он привез семена и сеянцы шелковицы, которые лично посадил в Александровском саду и в Кремле, раздал членам Московского общества сельского хозяйства. Предпринял он посадки шелковицы и в Санкт-Петербурге [3, с. 123-124].

В период с 1830-х по 1850-е годы А. Ф. Реброва избирали членом Обществ, таких как: Императорское московское общество сельского хозяйства, Главное московское общество улучшения овцеводства, Императорское московское общество испытателей природы, Кавказское общество сельского хозяйства, Императорское вольное экономическое общество, Императорское русское географическое общество и другие. Все это говорило о том, что А. Ф. Реброва ценили как личность, как умного человека, знатока по истории Северного Кавказа, который добился выдающихся результатов в области ведения прогрессивного хозяйствования [6, л. 10.об., 11.об.]

Практическая и научная деятельность А. Ф. Реброва по ведению шелководства были оценены высокими наградами не только на выставках в Санкт-Петербурге и Москве, но за рубежом. На международных выставках в Лондоне и Париже шелк, производимый в имении А. Ф. Реброва, по качеству и белизне был удостоен золотых медалей и дипломов [6, л. 10.об. - 12.об., 10, л. 21об. -22].

18 октября 1837 года в городе Ставрополе была проведена первая сельскохозяйственная выставка на Северном Кавказе, которую посетил император Николай I. Ее директором был назна- чен А. Ф. Ребров, как знаток по истории, быту и обычаям народов Северного Кавказа, разбиравшийся в своеобразных тонкостях отраслей сельского хозяйства. Выставка была организована и укомплектована при личном участии А. Ф. Реброва, а все представленные экспонаты были им предварительно изучены [4, л. 8 - 8 об.], [14, c. 61]. Для выставки в городе Ставрополе был предоставлен ставропольским 1 гильдии купцом Волобуевым в гостином дворе зал с двумя отдельными комнатами, в которых были расположены в симметричном порядке предметы по каталогу, в клетках были помещены животные и дикие птицы [4, л. 8], [23, с.4].

Император и сопровождавшие его лица с интересом осмотрели раздел выставки, в котором были сосредоточенны экспонаты из имения А. Ф. Реброва. Подойдя к шелку, император отметил: «Это у нас важная статья». Николай I был истинным ценителем шелковой одежды и отлично разбирался в этом вопросе. Далее вниманию императора была представлена тростниковая решетка, наполненная сребровидными коконами, а также коконы китайской породы «сина». Рассматривая коконы, император расспрашивал о породах и их разнице, откуда они были привезены. Заинтересовали императора и машинки: первая разматывающая шелк с коконов и вторая - тростильная, которые отличались от обыкновенных одновременным выполнением нескольких операций: трощения и сучения, при этом значительно сокращая время работы. Наиболее ценным экспонатом было улучшенное мотовило для шелкомотания (тростильно-сучильное для шелка) [4, л. 9об.], [22, с. 4].

После осмотра выставки императором была дана высокая оценка шелководческому делу А. Ф. Реброва. Впоследствии он писал: «...Удостоенный за сию промышленность десяти различных наград, я горжусь главнейшею из них, полученною мною в изустной благодарности от Его Императорского Величества, изъявленной мне в присутствие особ его окружающих и всей публики в Ставрополе в достопамятный день 18 октября» [5, л. 1], [11, с. 364]. Спустя 5 лет А. Ф. Ребров вспоминал: «... я имел счастье быть председателем Областной выставки, но в настоящих преклонных летах моих, я еще более гордился бы, если бы мог дожить до того, чтобы встретить соперничествующих мне в этой отрасли в России» $[5$, л. 1 об.].

Будучи настоящим патриотом, А. Ф. Ребров в печати настойчиво проводил мысль о том, что Россия способна самостоятельно удовлетворить потребность в сырье для отечественной шелкоткацкой промышленности. Занимаясь популяризаторской деятельностью в области развития и распространения шелководства, А. Ф. Ребров публиковал в газетах $[17 ; 18]$ и московских журналах $[19 ; 21 ; 23-25]$ свои статьи с научными результатами, выводами, насущными проблемами, препятствующими должному развитию шелководства не только на Кавказе, но и в России. 
Благодаря созидательной деятельности А. Ф. Реброва и его крестьян село Владимировка за короткий срок превратилось в настоящий оазис в Ногайской степи. Об имении помещика Реброва стало известно и за рубежом. Приезжающие на Кавказ путешественники старались при удобном случае побывать в нем.

В 1839 году семья ученых, путешественников Ксавье и Адель Оммер де Гелль посетили имение Владимировку. Еще в 1836 году Ксавье де Гелль был направлен в Россию для геологических, географических и этнографических исследований территории Кавказа, предгорий Каспийского моря. Результатом исследований стал 3-х томный труд «Les steppes de la mer Caspienne, Le Caucase, La Crimee et la Ruisse Meridionale» («Степи Каспийского моря, Кавказ, Крым и Южная Россия», Париж, 1843-1845 гг.). В сборе и обработке материала участвовала, путешествовавшая с ним, жена Адель. В 10-м номере «Журнала путешествий», издаваемого в Париже, Ксавье де Геллем была опубликована небольшая заметка, описывающая имение помещика Реброва: «Проезжая по Западным степям Каспия, я нашел одно из прекраснейших поместий на реке Куме, с. Владимировку г. Реброва. Тут видна широкая и разумная мысль во всем расположении этого замечательного имения... Солончаки, топкие и недоступные к возделыванию земли, превращены посредством канав в шелковичные плантации и виноградные сады» $[29$, c. $37-38]$.

Bo 2-м томе «Les steppes de la mer Caspienne, Le Caucase, La Crimee et la Ruisse Meridionale" Ксавье де Геллем было уделено внимание личностным качествам помещика Реброва: «Как экономиста и управленца, мистера Реброва можно сравнить с людьми более выдающимися в Европе, тем более у него имеется заслуга заниматься этими промышленными вопросами, что он не обладал, как другие, ресурсом специальной литературы». Об успешном развитии сельского хозяйства в имении Владимировке фрранцузский путешественник писал: «Каждый день мы посвящали два или три часа подробному осматриванию фрабрик, мельниц, прядильному производству, многочисленным плантациям в его заведении, которые не переставали возбуждать наше удивление и наш интерес» [31, s. 163].

Жена Ксавье - Адель в своей книге «Путешествие по Прикаспийским степям и югу России», по достоинству оценивала, оказанный помещиком, прием: «Мистер Ребров, хозяин Владимировки, предупрежденный нашим офицером, встречал нас у подножия лестницы, и мы при благополучном прибытии выразили свою вежливость господину. Он старался нас разместить в восхитительных квартирах на нижнем (первом) этаже, окна которого выходили на огромный и прекрасный сад, и где мы нашли бильярд и несколько выпусков иностранных журналов, которые дошли до берегов Кумы». Далее А. де Гелль описывала А. Ф. Реброва как радушного хозяина: «Было как- то хорошо, особенно когда мы имели редкое счастье, прибавляя все эти развлечения, к встрече с гостеприимным семейством. Эти деликатные расточительные хлопоты, показывали привязанность, которая пришла в наши сердца, и которая сделала настолько хорошим путешествие вне своей страны» [30, s. 221].

Особое внимание путешественницы было обращено на развитое хозяйство помещика Реброва в имении Владимировке: «Мягкость климата позволила ему сделать многочисленные плантации шелковицы, которые вполне имели успех, и организовал шелковые фабрики, продукты которых могут конкурировать с самыми прекрасными шелками Прованса». Таким образом, иностранцами оценивалось высокое качество «ребровского» шелка, который продавался в 3-5 раз дороже, чем шелк других поставщиков [30, s. 223].

А. Ф. Ребров добился того, что в 1847 году при императорском московском обществе сельского хозяйства был организован комитет шелководства, первым председателем которого был избран С. М. Маслов [3, с. 124]. В этом же году членом данного общества и комитета был избран и А. Ф. Ребров. С. М. Маслова связывали с А. Ф. Ребровым не только вопросы, касающиеся улучшения и распространения шелководства в России, но и дружба. Посетив еще в 1839 году имение Владимировку, С. М. Маслов дал высокую оценку его шелководческой деятельности: «Ребров... довел шелководное искусство до такой степени усовершенствования, что его шелка в продаже имеют высшую ценность пред всеми русскими шелками... Шелководное заведение г. Реброва есть истинно образцовое у нас заведение, в котором образовались у него собственные мастерицы и мастера шелковичного дела» [28, с. 223].

Высоко оценивался «ребровский» шелк и императорской семьей. В августе 1858 года А. Ф. Ребров преподнес императрице Марии Александровне 200 фунтов шелка, а также ткань, изготовленную на московской фабрике из его шелка. Императрицей было приказано сшить из ткани церковные облачения и отправить в Иерусалим [3, с. 124].

А. Ф. Реброва по праву считают основоположником научного, культурного и отечественного шелководства в России. Благодаря его деятельности Россия в первой половине XIX века не уступала в производстве шелка-сырца по белизне и качеству шелкам европейских и восточных стран. По инициативе и поддержке А. Ф. Реброва были открыты бесплатные школы для обучения шелководству. Безвозмездная раздача и высадка саженцев тутовых деревьев, способствовала развитию и постепенному распространению шелководства во всех губерниях страны. Проведение опытов и экспериментирование при изменении климатических условий, выведение новых пород шелкопряда и шелковичных деревьев, все это приводило к научному развитию шелководческой деятельности А. Ф. Реброва. 


\section{Источники и литература}

1. Алимирзаев Н. Я. Возникновение и развитие шелководства на Ставрополье (конец XVIII-XX вв.): диссертация канд. ист. наук. Ставрополь, 2011. 270 с

2. Беликов Г. А. Ставропольские генерал-губернаторы. Ставрополь: Ставропольское изд-во «Параграф», 2014. 176 c

3. Богословский В. В., Лейнвебер Е. Ф. А. Ф. Ребров - родоначальник научного шелководства в России // Третьи Ребровские музейно-краеведческие чтения (17-18 февраля 2011 года). Часть І. Материалы для биографии А. Ф. Peброва. Выпуск 1. Кисловодск: Изд-во МИЛ, 2012. С. 120-125.

4. Государственный архив Ставропольского края (далее - ГАСК). Ф. 79. О. 2. Д. 489.

5. ГАСК. Ф. 79. О. 2. Д. 878.

6. ГАСК. Ф. 79. О. 2. Д. 1632

7. ГАСК. Ф. 79. О. 1. Д. 1011

8. ГАСК. Ф. 79. О. 2. Д. 1753

9. ГАСК. Ф. 444. О. 1. Д. 289

10. ГАСК. Ф.1305. О. 1. Д.28

11. Запорожцева О. А. Деятельность Алексея Федоровича Реброва по внедрению прогрессивных методов хозяйствования на Ставрополье // Культура и общество: история и современность: материалы III Всероссийской (с международным участием) научно-практической конференции / под ред. О. Ю. Колосовой, Т. В. Вергун, Р. Ф. Гударенко. Ставрополь: АРГУС СТГАУ, 2014. С. 360-365

12. Иофе Г. Л. Основоположник культурного шелководства в России А. Ф. Ребров // Сборник научных трудов Ташкентского текстильного института. Вып. 6. Ташкент: Изд-во «ФАН» Узбекской ССР, 1958. С. 119-128.

13. Иофе Г. Л. У истоков науки о шелководстве и шелкопереработке // Механическая технология волокнистых материалов. Научные труды. Выпуск 20. Ташкент: Издательство «ФАН» Узбекской ССР, 1967. С. 247-254.

14. Кемпинский Э. В. Высочайший ревизор в Ставрополе: материалы по краеведению. Ставрополь: Кн. Изд-во 2004. $80 \mathrm{c}$.

15. Маслов С. А. О кресте на горе Св. Духа близ Нарзана в Кисловодске // Кавказ. 1848. №34. С.3.

16. Орудина Л. Г. У порога синих гор: исторические очерки / лит. запись И. В. Кузнецова. Ставрополь: КН. изд-во, 1983. 287 c

17. Ребров А. Ф. Замечания по предмету улучшения шелководства в Закавказких провинциях // Кавказ. 1854. №40 C. 160 .

18. Ребров А. Ф. О ближайших способах к правильному развитию в России улучшенного шелководства // Кавказ 1852. №21. С. $85-86$.

19. Ребров А. Ф. О новом шелкомотальном снаряде, изобретенном на Кавказе // Земледельческий журнал. 1831 №1. C. 141-152.

20. Ребров А. Ф. О разведении китайского шелка-сина в Кавказской области. (Донесение) // Земледельческий журнал. 1837. №1. С.103.

21. Ребров А. Ф. О шелководстве в Кавказской области, с сравнительными выводами шелководства в других местах // Журнал сельского хозяйства и овцеводства. 1842. №1 . С. 37-59.

22. Ребров А. Ф. О шелководстве и о посещении императором Николаем I первой сельскохозяйственной выставки в г. Ставрополе 18 октября 1837 года // Ставропольские губернские ведомости. 1905. №38. С. 4. - Ч. неофиц. (Наша старина).

23. Ребров А. Ф. О шелководстве в России // Земледельческий журнал, 1831. №1 . С. 130-140.

24. Ребров А. Ф. Отчет о шелководстве Г.Д.Ч. Реброва за 1834 г. // Земледельческий журнал. 1835. №21. С. $113-124$

25. Ребров А. Ф. Шелководство // Журнал сельского хозяйства и овцеводства. 1852. №2. С. 13-26.

26. Фадеев А. В. А.Ф. Ребров - помещик-рационалист // Кавказские Минеральные воды в описаниях, очерках, исследованиях за 200 лет. Том 3, конец XX - начало XX вв. / под ред. проф. В. А. Шаповалова, проф. К. Э. Штайн. Ставрополь: СГУ, 2011. С. 46-48.

27. Шаров Н. Н. Описание Кавказского шелководства. Тифлис: Типография канцелярии Главноначальствующего гражданской частью на Кавказе, 1891. 320 с.

28. Шелководство на Кавказе и за Кавказом // Кавказ. №54. 1851. С. 222-223.

29. Юрьев Н. Материалы для биографии Алексея Федоровича Реброва (26 марта 1864 г., село Владимировка на Кавказе) // Кавказские Минеральные воды в описаниях, очерках, исследованиях за 200 лет. Том 3, конец 20 - начало 21 вв. / под ред. проф. В. А. Шаповалова, проф. К. Э. Штайн. Ставрополь: СГУ, 2011. С. 36-42.

30. Adele Hommaire de Hell. Voyage dans les steppes de la mer Caspienne et dans la Russie Meridionale. Paris: Librairie de L. Hachette et C., 1860. $411 \mathrm{~s}$.

31. Xavier Hommaire de Hell Les steppes de la mer Caspienne, Le Caucase, La Crimee et la Ruisse Meridionale. Voyage pittoresque, historigue et scientifique // Paris: CHEZ P. BERTRAND, EDITEUR, LIBRAIRE DE LA SOCIETE GÉOLOGIQUE DE FRANCE, 1845. Tome second. $598 \mathrm{~s}$.

32. Klychnikov Ju. Ju. Aleksey Fedorovich Rebrov: A Functionary, Entrepreneur, and Patron // Russkaya Starina. 2014 No.3. P. $119-129$.

\section{References}

1. Alimirzaev N. Ja. Vozniknovenie i razvitie shelkovodstva na Stavropol'e (konets XVIII-XX VV.) (The emergence and the development of sericulture in the Stavropol region (late XVIII-XX centuries.): thesis. Stavropol', 2011. 270 p. (In Russian).

2. Belikov G. A. Stavropol'skie general-gubernatory (Stavropol governors-general). Stavropol': Paragraf publ., 2014. 176 p. (In Russian) 
3. Bogoslovskij V. V., Lejnveber E. F. A. F. Rebrov - rodonachal'nik nauchnogo shelkovodstva v Rossii (A. F. Rebrov - the founder of scientific sericulture in Russia) // Tret'i Rebrovskie muzejno-kraevedcheskie chteniya (17-18 fevralya 2011 goda) Part I. Materialy dlya biografii A. F. Rebrova. Issue 1. Kislovodsk: MIL publ., 2012. P. 120-125. (In Russian).

4. State archive of Stavropol Territory (GASK). F.79. Inv.2. D. 489. (In Russian)

5. GASK. F. 79. Inv. 2. D. 878. (In Russian).

6. GASK. F. 79. Inv. 1. D. 1011. (In Russian).

7. GASK. F. 79. Inv. 2. D. 1632. (In Russian).

8. GASK. F. 79. Inv. 2. D. 1753. (In Russian).

9. GASK. F. 444. Inv. 1. D. 289. (In Russian)

10. GASK. F. 1305. nv. 1. D. 28. (In Russian).

11. Zaporozhtseva O. A. Dejatel'nost'Alekseja Fedorovicha Rebrova po vnedreniju progressivnyh metodov hozjajstvovanija na Stavropol'e (The work of Alexei Fedorovich Rebrov to introduce advanced methods of management in the Stavropol region) // Kul'tura i obschestvo: istorija i sovremennost': materialy III Vserossijskoj (s mezhdunarodnym uchastiem) nauchnoprakticheskoj konferentsii. Stavropol': ARGUS publ., 2014. P. 360-365. (In Russian)

12. lofe G. L. Osnovopolozhnik kul'turnogo shelkovodstva v Rossii A. F. Rebrov (The Founder of Cultural Sericulture in Russia - A. F. Rebrov) // Sbornik nauchnyh trudov Tashkentskogo tekstil'nogo instituta. Issue. 6. Tashkent: Printing house «FAN》 publ., 1958. P. 119-128. (In Russian).

13. lofe G. L. U istokov nauki o shelkovodstve i shelkopererabotke (At the origins of the Science of Sericulture and Silk Processing) // Mehanicheskaja tehnologija voloknistyh materialov. Nauchnye trudy. Issue 20. Tashkent: Printing house «FAN》 publ., 1967. P. 247-254. (In Russian).

14. Kempinskij Eh. V. Vysochajshij revizor $\vee$ Stavropole: materialy po kraevedeniyu (The Highest Auditor in Stavropol: Materials on Local Lore). Stavropol', 2004. 80 p. (In Russian).

15. Maslov S. A. O kreste na gore Sv. Duha bliz Narzana $\vee$ Kislovodske (The Cross on the Mount of St. Spirit near Narzan in Kislovodsk) // Kavkaz. 1848. No. 34. P. 3. (In Russian).

16. Orudina L. G. U poroga sinih gor: istoricheskie ocherki (At the Threshold of the Blue Mountains: Historical Essays). Stavropol', 1983. 287 p. (In Russian).

17. Rebrov A. F. Zamechaniya po predmetu uluchsheniya shelkovodstva v Zakavkazkih provinciyah (Observations on the Improvement of Sericulture in Zakavkazsky Provinces) // Kavkaz. 1854. No. 40. P. 160. (In Russian).

18. Rebrov A. F. O blizhajshih sposobah k pravil'nom razvitiyu v Rossii uluchshennogo shelkovodstva (On the Immediate Ways to the Correct Development of the Improved Sericulture in Russia) // Kavkaz. 1852. No. 21. P. 85-86. (In Russian).

19. Rebrov A. F. O novom shelkomotal'nom snaryade, izobretennom na Kavkaze (About the new filature projectile, invented in the Caucasus) // Zemledel'cheskij zhurnal. 1831. No. 1. P. 141-152. (In Russian).

20. Rebrov A. F. O razvedenii kitajskogo shelka-sina v Kavkazskoj oblasti. (Donesenie) (On the Cultivation of Chinese SilkSina in the Caucasus region. (Report)) // Zemledel'cheskij zhurnal. 1837. No.1. P. 103. (In Russian).

21. Rebrov A. F. O shelkovodstve $v$ Kavkazskoj oblasti, s sravnitel'nymi vyvodami shelkovodstva $v$ drugih mestah (On Sericulture in the Caucasus Region, with Comparative Conclusions of Sericulture in Other Places) // ZHurnal sel'skogo hozyajstva i ovcevodstva. 1842. No. 1. P. 37-59. (In Russian).

22. Rebrov A. F. O shelkovodstve i o poseshchenii imperatorom Nikolaem I pervoj sel'skohozyajstvennoj vystavki v g. Stavropole 18 oktyabrya 1837 goda (On Sericulture and the Visit of the Emperor Nicholas I to the First Agricultural Exhibition in Stavropol on October 18, 1837) // Stavropol'skie gubernskie vedomosti. 1905. No. 38. P. 4. (In Russian).

23. Rebrov A. F. O shelkovodstve v Rossii (On sericulture in Russia) // Zemledel'cheskij zhurnal. 1831. No. 1. P. 130-140. (In Russian).

24. Rebrov A. F. Otchet o shelkovodstve G. D. Ch. Rebrova za 1834 g. (Report on sericulture G. D. Ch. Rebrov of 1834) /I Zemledel'cheskij zhurnal. 1835. No. 21. P. 113-124. (In Russian).

25. Rebrov A. F. SHelkovodstvo (Sericulture) // ZHurnal sel'skogo hozyajstva i ovcevodstva. 1852. No. 2. P. 13-26. (In Russian).

26. Fadeev A. V. A. F. Rebrov - pomeschik-ratsionalist (A. F. Rebrov-landowner-rationalist) // Kavkazskie Mineral'nye vody v opisanijah, ocherkah, issledovanijah za 200 let. Vol 3, konets 20 - nachalo 21 vv. Stavropol': SSU publ., 2011. P. 4648. (In Russian).

27. Sharov N. N. Opisanie Kavkazskogo shelkovodstva (Description of the Caucasian sericulture). Tiflis: Printing Office of the Office of the Chief Civilian in the Caucasus publ., 1891.320 p. (In Russian).

28. Sjelkovodstvo na Kavkaze i za Kavkazom (Sericulture in the Caucasus and beyond the Caucasus) // Kavkaz. 1851. No. 54. P. 222-223. (In Russian).

29. Yur'ev N. Materialy dlya biografii Alekseya Fedorovicha Rebrova (26 marta 1864 g., selo Vladimirovka na Kavkaze) (Materials for the biography of Alexei Fedorovich Rebrov (March 26, 1864, the village of Vladimirovka in the Caucasus) II Kavkazskie Mineral'nye vody v opisaniyah, ocherkah, issledovaniyah za 200 let. Vol 3, konec 20 - nachalo 21 vv. Stavropol' SSU publ., 2011. P. 36-42. (In Russian).

30. Adele Hommaire de Hell. Voyage dans les steppes de la mer Caspienne et dans la Russie Meridionale. Paris: Librairie de L. Hachette et C., 1860. $411 \mathrm{~s}$.

31. Xavier Hommaire de Hell Les steppes de la mer Caspienne, Le Caucase, La Crimee et la Ruisse Meridionale. Voyage pittoresque, historigue et scientifique // Paris: CHEZ P. BERTRAND, ÉDITEUR, LIBRAIRE DE LA SOCIÉTÉ GÉOLOGIQUE DE FRANCE, 1845. Tome second. $598 \mathrm{~s}$.

32. Klychnikov Ju. Ju. Aleksey Fedorovich Rebrov: A Functionary, Entrepreneur, and Patron // Russkaya Starina. 2014. No. 3. P. $119-129$ 


\section{Сведения об авторе}

Запорожцева Ольга Алексеевна - аспирант кафедры истории России гуманитарного института Северо-Кавказского фредерального университета (Ставрополь) / qlbz1992@mail.ru

Information about the author

Zaporozhtseva Olga - postgraduate, Chair of Russian History, Institute of Humanities, North Caucasus Federal University (Stavropol) / qlbz1992@mail.ru 